\title{
Discussion: Deconstruction of the Maureen platform and
}

\section{loading column}

\section{P. Broughton, R. L. Davies and M. Green}

This is a transcription of the discussion which followed the authors' presentation of their paper at an ICE Ordinary Meeting on 16 June 2004.

\section{Peter Blair Fish, CBI John Brown}

You showed some very interesting marine operations, particularly to get the deck off the barge and then to get the deck onto the quay, and you talked about some of the tricky work there. I wonder what systems did you use to control those operations to avoid things going wrong-was it purely mechanical or was it computer control and, if so, what sort?

\section{Authors' reply}

I do not think there was anything particularly special. There were no sophisticated measuring devices or so forth, surprisingly. When we did the separation of the deck there were people running about checking the gaps between the legs and so forth and then we crudely adjusted the trim on the barge just to make sure we got it roughly equal, about 10 in or thereabouts, $30 \mathrm{~cm}$ gaps throughout the ten leg positions. It was a rough target, and it was using the ballast system on the barge basically at that stage. I do not believe we had any particular sophisticated systems for skidding the deck ashore. If you can control the barge freeboard to $\pm 1 \mathrm{~mm}$ it is pretty good going.

\section{Peter Blair Fish, $C B I$ John Brown}

What role did the reused steel structure really play in these new quays? You showed the temporary concrete structure that was used to help support the three steel columns to get it into its final position but it seems that if you had those concrete cells and the rock behind it should have been sufficient. What part did the steel structure you were reusing actually play in the final quay wall?

\section{Authors' reply}

There were three methods for dealing with this dear old lady. One was burial, another was cremation, and the third being organ transplant. I do not beat about the bush, it was a burial. So these elements you could say were hidden or buried.

The tank bases do have a structural purpose. The concrete segments were all tied together themselves. The pre-stressing strands that were used in the original concrete rings were used to tie back the front of the quay wall onto these tank bases.

\section{Peter Blair Fish, CBI John Brown}

In very rough terms, you haven't talked about cost, and I'd ask you: what was the deconstruction cost as a proportion of the original construction cost?

\section{Authors' reply}

The deconstruction costs referred to in the paper, which includes the refloat itself, the moving of the Maureen steel gravity platform, removing the Moira wellhead structure, removing the concrete loading column, removing the Moira pipeline, and the full deconstruction, were quoted as about $£ 150$ million. Now it depends what you include in the $£ 150$ million; there were some other costs, shall I say sub-costs, which started before we started the project, shall we say study work for many years, and it is amazing how study work builds up costs. There are also the costs of plugging and abandoning the wells. We managed to get them done for about $£ 0.5$ million each, which we were told was good. So the overall figure, everything included, went to slightly over the $£ 200$ million mark. This element of work, which is the deconstruction, culminating with the new dock facility, is about $£ 75$ million, and around $£ 70$ million or so was spent on the refloat and tow, which gives you around $£ 150$ million.

\section{Stan Rogers, ex-Phillips Petroleum}

Regarding the coal tar epoxy on the inside of the tanks and cathodic protection as an accessory, in case there was a breakdown in the epoxy, did the cathodic protection have to be in use at all?

\section{Authors' reply}

After we cleaned the inside of the tanks they were in almost pristine condition. There was hardly any rust on the internal walls; the only rust was around where some of the attachments were located. I think with regard to the overall structure, it is a shame to talk about cutting something like this up. The structure in itself was in a very good shape throughout. 


\section{Phil Smedley, PAFA Consultants}

I am sure you looked at many scenarios for the deconstruction and decommissioning of the platform including the unacceptable deep-sea disposal. Could you say anything about the relative risks and costs-risks in terms of safety and pollution-of this method compared with deep-sea disposal if it was allowed.

\section{Authors' reply}

It is impossible to say because you have to take each scenario to a culmination. What we know is that deep-sea dumping was curtailed as an option (following Brent Spar). You are comparing something you did with something that was not possible.

We did a good job controlling environmental issues, and it is summarised in one of the tables in the paper. In terms of where materials went and how much we released by accident, it was very small. We were satisfied with it really.

\section{Mike Banning-Lover, Offshore Design Engineering Ltd}

I was deeply involved in the construction of the articulated loading column (ALC). A lot of hematite was put in as ballast. There is no mention of the removal of the material.

\section{Authors' reply}

We did not remove any materials during marine operations.

\section{Stewart French, Offshore Design Engineering Ltd}

I was a member of the on-site team for this project. Although the ballast was not removed when the ALC was transferred to the inshore location, after the ALC was beached the ballast was removed by transporting it along the column to its open end. It had the consistency of a finely divided solid looking rather like sand-blasting grit. The ballast does not form part of the new ALC breakwater construction as it was recycled.

\section{Mike Banning-Lover, Offshore Design Engineering Ltd} Was there any consideration of lifting the deck with the modules on?

\section{Authors' reply}

The answer is yes we could have, but then you have got to think about the actual deconstruction of these elements in the yard. The problem is getting structural materials down to ground level where you can deal with it. It is much easier dealing with modules at ground level, rather than dealing with them stuck up above the deck. We may have had to have a stronger barge, as we would have had roughly 16-17 $000 \mathrm{t}$ on it, as opposed to the $11000 \mathrm{t}$ we had, so it may have been possible, but I think the contractor took the right approach-take the modules off first before removing the lower deck. I was a bit anxious about the idea of walking around with the modules hanging from the end of a hook. It did not look too sanitary at the beginning, but obviously it worked well. We took the right decision.

\section{Mike Banning-Lover, Offshore Design Engineering Ltd} What about the knee braces between the deck and the structure that had to be jacked into position during construction?

\section{Authors' reply}

The knee braces were cut for sure. A full engineering effort had been put into each phase of the work. One thing I learnt about Aker, and recognising that it was a deconstruction job, there were things that they did that I would not necessarily have thought of doing. Using timber shim plates for example, and allowing for deformation-significant deformation-because they were going to deconstruct the deck and some of the node positions on the deck looked very sad as we were skidding on to the quay, whereas for a new build you could not have done that.

In trying to remove the deck and all the modules, one of the problems that Aker would have had was once we had headed for shore was the yard cranage at higher elevations and they had taken all of this into account in their deconstruction manual.

\section{Don Smith, Association of Oil and Gas Producers}

We've been approached by the World Bank to try to put together some industry guidelines on decommissioning and I was just wondering what your view is: do you think we can use land reclamation as a cornerstone of our decommissioning policy in the future and do you think that is an environmentally friendly way forward?

\section{Authors' reply}

Do you mean hide steel in some big quarry or something? I do not see this as being a problem, but you are going to have to get all the necessary approvals for doing it, and also you do not want to be transporting it too far, once you have got it ashore. You do not want to be moving that amount of steel around. The easiest way of transporting anything is by water. I think most of the steel structures from the North Sea will be cut up and sold for scrap, that is my personal view.

\section{Mark Knight, CBI John Brown}

You said that all the operations were carefully engineered. What were the critical design conditions for the structures during dismantling?

\section{Authors' reply}

One of the most sensitive conditions-and we did identify this during the phase when we were doing the actual refloat work-was the deep submergence, because do not forget there is no internal pressure inside the three storage tanks at that stage as they were opened up-we are dealing with $112 \mathrm{~m}$ of draft. So before we started this phase of the work we undertook some special analyses of that bottom section of the tank, to look at it to make sure that it was robust enough, because it had never been subject to that kind of pressure before.

\section{Chris Faye, Shell}

Just to give you, by way of example, the analysis of Brent Spar for the deep-water disposal. It was fully expected that probably three people would have been killed if the platform were brought ashore (for deconstruction).

I would just like to make one comment ten years after Brent Spar. Essentially, you said you have proposed a landfill. In a world now, whereby landfill is frowned upon for rubbish and, of course, recycling is fashionable, to what extent has Phillips or anyone tried to work out the energy balance for the case of 
emissions? What frightened us when we looked at the Brent Spar was when you actually did the calculations on the energy consumed and the various other things and what you put into the environment in the process, it is unbelievably high. This needs to be considered in the light of the environmental debate about what is coming out of the back of a car, which ignores what has been done to get the petrol into that car in the first place. In answer to the gentleman at the back I believe that somebody needs to revisit the total balance when we are talking about decommissioning.

People are not aware that seven times the tonnage of Brent Spar sank on the same day that the Brent Spar was due to be disposed. They were not anywhere near as clean as Brent Spar was. You talk here about a breakwater-what is the reuse? This seems to be blind to the total balance of what we are talking about. What I am saying is that we should revisit it and see what the calculations reveal.

\section{Authors' reply}

One of the options that we looked at when we were disposing of these tank bases was getting them into a dry dock, and we actually calculated that there was somewhere between 8000 and 10000 lorry loads of orecrete to be removed, and the thought of doing that didn’t appeal to anybody.

I think we did the best that we could actually, under the circumstances. There were some energy calculations done, but by the time you get into a project you tend to just put that aside and just get on with what you think is the best solution.

\section{Neil Sandberg, Sandbergs}

You mentioned the problems you had with low specific activity (LSA) scale and you mentioned it was $2 \%$ of what you anticipated. Within your contract, which was a lump sum, who takes on the risk of that?

\section{Authors' reply}

There were two elements of this work which were physically problematical. Both of these had contractual implications. One of these physical problems was the tank cleaning and the other was the LSA scale. The LSA scale was dealt with using a target quantity and costs schedule of rates to apply beyond the target. Clearly, the contractor appeared to have a vested interest in increasing the estimate of the amount of this material. We had a vested interest in getting the estimate down to within the original target. We adopted procedures-Dr Peter Read did all our work for us-to get that estimate down.

\section{Peter Read, PARSEC Engineering}

This new quay area was, in fact, rather badly contaminated industrial land from before. Its levels of polychlorinated biphenyl (PCB) were recorded as some of the highest in the Norwegian waters. So, to some extent, two of the environmental targets, if you like, have been achieved here, and that's that everything used in the new quay in the way of old components from Maureen Alpha did, in fact, not cost us anything in terms of our energy penalty, and the second is that they do serve a useful purpose in terms of permanent containment for what is, after all, a very nasty environmental contaminant.

\section{Authors' reply}

If I can just come back to this LSA scale. There was, from the outset, some nervousness as to what the final estimate would be with regard to it, because we were told that at that particular point in time there were several locations in Norway with drums of this LSA material stuck on the quayside. One of the objects of the exercise of the deconstruction is to gradually reduce your liabilities and responsibilities, and together we saw this work, that leaving the drums on the quayside to be dealt with by someone else years later is not the right answer, so I think we adopted a very sensible scientific and pragmatic solution to the LSA scale.

\section{Nick Hughes, Amec}

A project like this involves as much engineering as the initial design engineering for the installation and the mooring in the first place. But it is significant that, when Maureen was originally designed, the full decommissioning was not taken into account, and if we had taken the full decommissioning into account, perhaps there would have been additional measures taken during the initial construction to facilitate the decommissioning. We have now learnt the lesson, but we still have the residual of a large number of platforms out in the North Sea, where no thought or work or was done on how they might be finally decommissioned.

\section{Authors' reply}

That is a valid comment. I think the only other thing I would say is that, from the beginning, both of the structures at the Maureen field were somewhat unique, and the main platform was also designed with the idea in mind that it could be reused somewhere else. Part of the problem with full oil field reuse is getting other oil companies' project management signed up. There was initially a lot of apprehension about whether we would actually refloat the platform or not. By the time we got to the platform refloat there were no horses in the box ready for the race. So I think Maureen is unique. This reuse was well thought out, at the beginning, as a possibility.

\section{Mark Knight, CBI John Brown}

I think a number of us saw your advertisement on the website with 'for sale' across the picture of Maureen before you actually took it out. Did you actually get any more interest in it once you had got it floating and demonstrated that it could be relocated?

\section{Authors' reply}

On the platform sale, no, I do not think there was any real pick-up in interest after refloat. All sorts of potential opportunities had been pursued at that point in time, including schemes to move the platform to West Africa and things like that. The North Sea had limited applications because it was critical in terms of water depth due to large wave heights, while in West Africa it is less sensitive to water depth because the wave heights are much smaller. None of these schemes materialised at all. It is a shame. I think I made the point in the presentation that once you got to the actual stage of platform refloat and there were no schemes for full oil field reuse, then the thing to do is to forget it and go for full deconstruction. 
Mark Knight, CBI John Brown

You talked about LSA scale in the topsides, but you've not mentioned the tanks-was there anything found in those storage tanks?

\section{Authors' reply}

No, there was not. I am not a process engineer, but what they have told us is that the only product that went into the tanks was processed oil-there was no treated water going into the tanks-so when the oil product was going through the various stages of the process train, the LSA was being dropped out and by the time it got to the end and deposited in the tanks it did not contain any LSA scale.

Neil Glover, GMOC Ltd

I would just like to make a point on the reuse: I think it is a great shame that this was not done, especially when Peter told us the platform came out in very good condition. 